УДК 373.02(477)

DOI:

Ванда Вишківська, кандидат педагогічних наук, доцент кафедри теорії та історї педагогіки

Національного педагогічного університету імені М.П. Драгоманова

Олександра Шикиринська, кандидат педагогічних наук, доиент кафедри дошкільної та початкової освіти

Вінницького державного педагогічного університету імені Михайла Коцюбинського

\title{
ОРГАНІЗАЦІЯ ПРОЦЕСУ НАВЧАННЯ В НОВІЙ УКРАЇНСЬКІЙ ШКОЛІ: ТЕОРЕТИКО-ПРАКТИЧНИЙ АСПЕКТ
}

У статті висвітлено особливості науково-методичного забезпечення процесу реформування загальної середньої освіти через призму ідей Нової украӥнської школи. Наголошено на необхідності розвитку мультимодальної грамотності, впровадження інформаційних технологій, організації роботи над творчими проектами як засобами розвитку ключових компетенцій сучасних школярів. Акцентовано на актуальності переосмислення ролі вчителя в організації освітнього процесу та удосконаленні системи підготовки педагогічних кадрів.

Ключові слова: реформування освіти; особистісно-орієнтований підхід; діяльнісний підхід; компетентнісний підхід; Концепція НУШ; мультимодальна грамотність; інформаційні технологї; метод проектів.

Jim. 14.

Vanda Vyshkivska, Ph.D.(Pedagogy), Associate Professor of the

Theory and History of Pedagogy Department, Mykhaylo Drahomanov National Pedagogical University Oleksandra Shyhyrynska, Ph.D.(Pedagogy), Associate Professor of the Preschool and Elementary Education Department Mykhaylo Drahomanov National Pedagogical University

\section{ORGANIZATION OF THE EDUCATION PROCESS IN THE NEW UKRAINIAN SCHOOL: THEORETICAL-PRACTICALASPECT}

The article deals with the peculiarities of scientific and methodological support of the process of reforming the general secondary education through the lens of innovation of the New Ukrainian School, which approves the personality-oriented model of education, based on the ideas of child-centrism and the basic provisions of the activity approach as the basis of pedagogy of partnership (cooperation, cooperation), based on the principles of humanism, dialogical subject-subject interaction between all participants of the educational process (student school - community - family), creative approach to development of each individual, understanding, joint actions and support conscious of personal responsibility for the results of social partnership. The main strategic priorities of the reorganization of the educational process are defined: a clear focus on the basic values of educational development, modernization of the content of education, reliance on competently oriented learning as a new type of organization of the educational process, the use of personality-oriented teaching methods and technologies, improving training. The need to develop multimodal student literacy, which includes various methods of working with linguistic, visual, audio, gestural and spatial information, is emphasized, which in turn provides a high level of activity in the learning process. It is noted that the use of game and information technologies, the implementation of cross-curricular lessons, the involvement of students with their own gadgets (technology "bring your device to the lesson"), the organization of work on creative projects as a means of developing the key competences of modern schoolchildren will contribute to increasing the interest in learning. An emphasis is placed on the urgency of rethinking the functions of the teacher who should act as the organizer and coordinator of the actions of the students, their mentor, facilitator and tutor; must have academic freedom, have advanced project management skills and organize a childcentered educational process.

Keywords: an education reform; personality-oriented approach; business approach; competence approach; NUSH concept; multimodal literacy; Information Technology; a method of projects.

$\Pi$ остановка проблеми. Рівень розвитку освіти та науки значною мірою обумовлюють збереження економічного і культурного потенціалу українського суспільства. Подальша модернізація школи, інтеграція України в інтегровану світову культуру, спонукають до вироблення нових підходів до організації педагогічного процесу,

(C) В. Вишківська, 
переосмислення соціальних цілей освіти, якісного поглиблення реформ.

На початку двадцять першого століття за підсумками сесій ЮНЕСКО були проголошені засади створення світового суспільства знань: свобода вираження думок, якісна освіта для всіх, загальний доступ до інформації і знань, повага до культурного і мовного різноманіття тощо. Зазначені концепти, відповідно, вимагають розробки нових освітніх стандартів, орієнтованих на забезпечення учнів фундаментальними знаннями, на розвиток здібностей і підвищення рівня загальної грамотності.

Аналіз основних досліджень і публікацій. Реформування системи освіти вивчалося такими дослідниками, як І. Бестужев-Лада, Л. Даниленко, В. Кремінь, К. Корсак, І. Підласий та ін. Кращому розумінню основних тенденцій світового і вітчизняного розвитку освіти в кінці ХХ ст. сприяли роботи таких дослідників, як Б. Гершунський, І. Зязюн, М. Кларін, В. Кремень, В. Луговий, В. Лутай, М. Лукашевич, Д. Приходько, М. Скаткін та ін. Проблемам реформування освіти на сучасному етапі та актуальним питанням розбудови української національної школи присвячені роботи А. Богданової, Т. Лукіної, Т. Палій, О. Савченко та інших. Аналізові реалії і перспектив розвитку Нової української школи в контексті реформування загальної середньої освіти присвячені праці Л.А. Онищук.

Метою даної статті $\epsilon$ аналіз теоретикометодичних аспектів організації процесу навчання в умовах Нової української школи у контексті актуальних ідей реформування сучасного освітнього процесу.

Виклад основного матеріалу. Інтегральною основою сучасної парадигми освіти, на засадах якої здійснюється реформування української школи, як зауважує О.I. Ляшенко, має бути комбінація основних положень особистісно орієнтованого, діяльнісного і компетентнісного підходів [7].

Розглянемо особливості реалізації цих підходів в освітньому процесі НУШ.

Особистісно орієнтований підхід до навчання як методологодидактична основа реалізації процесу навчання забезпечує задоволення освітніх потреб учнів відповідно до їхніх пізнавальних інтересів та 3 урахуванням особливостей інтелектуального, емоційного і фізичного розвитку.

Філософія НУШ утверджує особистісноорієнтовану модель освіти, засновану на ідеях дитиноцентризму, що передбачає максимальне наближення навчання і виховання конкретної дитини до іï сутності, здібностей і життєвих планів, забезпечення морально-психологічного комфорту, відмови від орієнтації освітнього процесу на середнього школяра [6].

На засадах діяльнісного підходу як основи педагогіки партнерства (співробітництва), яка, в свою чергу, грунтується на принципах гуманізму, діалогічної суб'єкт-суб' єктної взаємодії між усіма учасниками освітнього процесу (учень - школа громада - родина), творчого підходу до розвитку кожної особистості, взаєморозуміння, співдії і підтримки, усвідомленої особистої відповідальності за результати, соціального партнерства, здійснюється інтеграція змісту, форм та методів навчання, реалізація багатосторонніх міжпредметних зв'язків, упровадження навчальних проектів [6].

Щодо особливостей реалізації ідей компетентнісного підходу, то слід зауважити, що у Концепції Нової української школи наголошено на необхідності спрямування навчання на отримання якісного результату, вираженого через сукупність розвинутих ключових компетентностей учнів, структури знань, поглядів, ціннісних орієнтирів. Акцентовано і на необхідності підготовки до самореалізації в професії і житті, формування особистості, патріота, інноватора, здатного конкурувати на ринку праці, розвивати економіку, навчатися неперервно впродовж життя [6].

У термінологічному полі компетентнісного підходу, як зауважує І.П. Мединцева, виділяють два базових поняття: компетенція (сукупність взаємопов'язаних якостей особистості, що задаються по відношенню до певного кола предметів і процесів) і компетентність (володіння людиною відповідною компетенцією, що включає iii особистісне ставлення до неї і предмету діяльності). Визначення ключових компетенцій і їх систем становить і на сьогодні чи найбільший науковий інтерес. При цьому використовуються і європейська система ключових компетенцій, i власне українські класифікації, в складі яких представлені ціннісно-смислова, загальнокультурна, навчально-пізнавальна, інформаційна, комунікативна, соціально-трудова компетенції та компетенція особистісного самовдосконалення. Категорія “компетентність”, у свою чергу, виражає значення традиційної тріади “знання, вміння, навички” і служить сполучною ланкою між їі компонентами; може бути визначена як поглиблене знання предмета або освоєне уміння; передбачає постійне оновлення знань, володіння новою інформацією для успішного вирішення професійних завдань в даний час і в даних умовах; включає в себе як змістовний (знання), так і 
процесуальний (вміння) компоненти [8]. У концепції НУШ визначено 10 ключових компетентностей: спілкування державною (і рідною у разі відмінності) мовами, спілкування іноземними мовами, математична компетентність, основні компетентності у природничих науках і технологіях, інформаційноцифрова компетентність, уміння вчитися впродовж життя, ініціативність і підприємливість, соціальна та громадянська компетентності, обізнаність та самовираження у сфері культури, екологічна грамотність і здорове життя [6].

Відтак, очевидно, що актуальним стає питання про модернізацію змісту освіти, що передбачає створення нових державних стандартів та освітніх програм для всіх рівнів повної загальної середньої освіти, оновлення навчально-методичного забезпечення освітнього процесу на засадах компетентнісного підходу, їх реалізацію за допомогою інноваційних засобів навчання i педагогічних технологій в сучасному інформаційно-освітньому середовищі [7].

На домінуючу роль інтересів особистості, яка здатна “жити в умовах насиченого і активного інформаційного середовища і реалізовувати потреби в новому рівні наукової грамотності, що враховує інтегративні тенденції розвитку науки і техніки", спрямована і парадигма особистісноорієнтованого виховання і навчання. Реалізація такої, на перший погляд не нової вимоги, потребує все ж таки оновлення та осучаснення існуючих підходів до організації освітнього процесу, зорієнтованого на потреби суб'єктів навчання.

Такому оновленню, на нашу думку, сприяє формування високого рівня мультимодальної грамотності учнів, яка $\epsilon$ інтегративною щодо “базових спеціальних сучасних знань та умінь”. Обгрунтуємо таку думку.

Термін “мультимодальна грамотність” був введений Новою лондонською групою для позначення грамотності, що включає різні прийоми роботи з мовною, візуальною, звуковою, жестикуляційною і просторовою інформацією [2].

У розрізі означеної нами проблеми значущість сформованості мультимодальної грамотності пояснюється тим, що сучасні діти мало читають. А оскільки читання є одним із найскладніших видів розумової діяльності, то сьогодні науковцями розглядається такий термін, як “нове читання” читання-перегляд і читання по діагоналі, яке дозволить перенести сформований ще у дитячі роки досвід роботи з екраном (телевізор, комп'ютер) на роботу з навчальним текстом. Як зауважує Г.М. Гич, “діти, народжені в Інтернеті, не можуть сприймати лінійний текст так, як попередні покоління. Кліпове мислення, якому притаманні фрагментарність, швидкість, перестрибування з однієї картинку на іншу, змінює сучасних учнів" [3]. Тому учителеві слід уникати довгих текстів та чітко структурувати інформацію, аби забезпечити iï цілісне сприйняття та осмислення. Також полегшити сприймання великих об'ємів інформації допоможе створення з дітьми, чи використання вчителем під час пояснення нового матеріалу ментальних карт [13].

До того ж вчителі-практики констатують, що діти, які прийшли сьогодні до Нової школи, мають порушення мовленнєвого та когнітивного розвитку, $\epsilon$ гіперактивними та неуважними, схильними до аутизації. І водночас дуже допитливими. Відтак, аби зарадити цим проблемам, уроки мають бути організовані так, щоб вони були цікавими для учнів. Розв'язати завдання стимулювання інтересу до навчання можна шляхом використання ігрових технологій, проведення міжпредметних уроків, залучення до процесу навчання власних гаджетів учнів (технологія “принеси свій пристрій на урок”). Впровадження інформаційних технологій у навчання значно урізноманітнює процес сприйняття і відпрацювання інформації. Завдяки комп'ютеру, Інтернету і мультимедійним засобам учням надається унікальна можливість оволодіння великим об’ємом інформації з іiі подальшим аналізом і сортуванням. Значно розширюється і мотиваційна основа навчальної діяльності.

Неабияку роль відіграє і створена вчителем позитивна психологічна атмосфера, яка дозволить дітям відчути себе по-справжньому суб' єктами навчання: дорослими, самостійними, відповідальними.

Зауважимо також, що спостереження педагогів-практиків свідчать сьогодні про неналежне сприйняття дітьми підручників через надмірну їх завантаженість інформаційним матеріалом. Учні, особливо початкової школи, більше орієнтовані на зорове сприймання інформації. Тому і навчальна книга має нести знання через образи: коли всю навчальну інформацію подано так, щоб очі реагували на неї як на цілісну картинку, а не як на лінійний текст певного обсягу [3].

Концепція НУШ покликана також наблизити навчання до життя. Розв'язання такого завдання вимагає переосмислення функцій вчителя, який має виконувати роль організатора і координатора дій учнів, що перебуває в авангарді суспільних та освітніх перетворень, умотивований, компетентний, який виконує в освітньому процесі ролі наставника, коуча, фасилітатора і тьютора, має академічну свободу, володіє навичками випереджувального проектного менеджменту (планування й 
організації навчання, розроблення навчальнометодичного забезпечення, оцінювання та ін.), самостійно й творчо здобуває інформацію, організовує дитиноцентрований процес, трансформуючи методи, прийоми і технології навчання залежно від запитів і потреб замовників освітніх послуг, формуючи бачення на сучасний світ та місце в ньому [6]. Такі вимоги до вчителя вимагають і певної переорієнтації системи їхньої підготовки у ЗВО. Як зауважують В.Б. Вишківська, С.А. Кушнірук, фахова підготовка майбутніх учителів на сучасному етапі має забезпечувати їхню готовності до вирішення професійних завдань в умовах концептуальної перебудови загальноосвітньої школи та формування творчого підходу до виконання професійних обов'язків [1].

За необхідне вважаємо звернути увагу і на актуалізовану Концепцією НУШ значущість розвитку критичного мислення та дослідницьких здібностей учнівської аудиторії. Вирішити означену проблему пропонується, в тому числі, через організацію творчих проектів, які дозволяють ефективно активізувати навчальнопізнавальну діяльність. Метод передбачає визначення цілей дослідницької, практичної або творчої діяльності, позначення проблеми, висування гіпотези зі способами їі вирішення, формулювання конкретних завдань проекту, збір даних, їх аналіз та обробку, складання плану, його практичне виконання, звіт про виконану роботу і іiї обговорення [12].

Г.К. Селевко визначає проект як спеціально організований педагогом і самостійно реалізований тими, хто навчається, на основі суб“єктивного визначення мети комплекс дій, що завершуються створенням продукту, який складається з об‘єкта праці, виготовленого у процесі проектування, і його представлення у вигляді усної чи писемної презентації [10]. О.І. Савенков, у свою чергу, зауважує, що розробка проекту обов'язково передбачає створення певного продукту внаслідок творчої або дослідницької діяльності, розв'язання творчого практичного завдання [9].

Таке розуміння науковцями сутності методу проектів робить його особливо актуальним в умовах НУШ, оскільки він дозволяє враховувати індивідуальні особливості кожного учня (рівень інтелектуального, морального, фізичного розвитку дитини), сприяє розв'язанню проблеми мотивації, створюючи позитивну атмосферу навчання, навчаючи дітей застосовувати свої знання на практиці для розв'язання життєвих і особистісних проблем.

Актуальний метод проектів і тому, що сприяє розвитку активного самостійного мислення учнів і орієнтує їх на спільну дослідницьку роботу, що, в свою чергу, виховує такі моральні цінності, як взаємодопомога і вміння співпереживати, формує творчі здібності, комунікативні навички, культуру спілкування, вміння коротко і доступно формулювати думки, терпимо ставитися до думки партнерів по спілкуванню, розвивати вміння здобувати інформацію з різних джерел.

Висновки. Отже, організація процесу навчання в умовах НУШ вимагає переосмислення його концептуальних засад, осучаснення змісту освіти та оновлення системи використовуваного методичного інструментарію.

\section{ЛІТЕРАТУРА}

1. Вишківська В.Б., Кушнірук С.А. До проблеми формування професійної компетентності вчителя Нової української школи. Науковий часопис: 3-к наукових праць "Педагогічні науки, реалії та перспективи. 2018. Серія 5. Випуск 64. С. 44-48.

2. Гендина Н.И. Информационная грамотность в контексте других видов грамотности: даиджест зарубежного опыта. Школьная библиотека. 2009. №. 910. C. $28-39$.

3. Гич Г.М. Учні Нової української школи як носії “нової грамотності” і суб'єкти освітнього процесу. Мистецтво та освіта. №1 (91). 2019. С.12-14.

4. Гич Г. М. “Кліпове мислення” дітей та підлітків як феномен сучасного навчального процессу. Вересень. 2014. № 3-4. С. 14-19; “Кліпове мислення” молоді: ворог чи друг навчання? Наукові праці ЧДУ ім. Петра Могили: наук.-метод. вид. Вип. 257. Т. 269. Педагогіка. Чорноморський державний університет ім. П. Могили. Миколаїв, 2016. С. 38-42.

5. Колесникова И. А. Новая грамотность и новая неграмотность двадцать первого столетия. Непрерывное образование: XXI век. Выпуск 2. 2013. DOI: 10.15393/j5.art.2013.2091

6. Концепція Нової української школи: Концептуальні засади реформування середньої школи. Міністерство науки і освіти України. Київ, 2016. 34 с.

7. Ляшенко О.І. Проблеми модернізації змісту освіти в умовах реформування української школи. Педагогіка і психологія. 2018. №4. С. 5-11.

8. Мединцева І. П. Компетентнісний підхід в освіті. Педагогічна майстерність: матеріали II Міжнар. науч. конф. (м.Москва, грудень 2012 року)

9. Савенков А.И. Методика учебного исследования и проектирования в практике начального обучения. Начальная школа. 2012. № 9. С.54-61.

10. Селевко Г. К. Энциклопедия образовательных технологий: в 2 т. Серия “Энциклопедия образовательных технологий”. Москва, 2006. Т. 1.2006. 535 с.

11. Универсальные компетентности и новая грамотность: чему учить сегодня для успеха завтра. Предварительные выводы международного доклада о тенденциях трансформации школьного образования / И. Д. Фрумин, М. С. Добрякова, К. А. Баранников, И. М. Реморенко; Национальный исследовательский университет “Высшая школа экономики”, Институт 
образования. Москва, 2018. 28 с. Современная аналитика образования. № 2 (19).

12. Федоров А.В. Развитие медиакомпетентности и критического мышления студентов педагогического вуза. Москва, 2007. 606 с.

13. Шикиринська О.В., Вишківська В.Б., Александрович Т.В. Ментальні карти у розвитку математичної компетентності майбутнього вчителя початкової школи. Актуальні проблеми формування творчої особистості педагога в контексті наступності дошкільної та початкової освіти : збірник матеріалів II Міжнародної науково-практичної Інтернет-конференції (Вінниця, ВДПУ імені Михайла Коцюбинського, 17-18 квітня 2019 р.) / за ред. О.А.Голюк ; Вінницький державний педагогічний університет імені Михайла Коцюбинського, факультет дошкільної, початкової освіти та мистецтв. Вінниця, 2019. Вип. 8. с. 183-185.

14. Фельдштейн Д. И. Изменяющийся ребенок в изменяющемся мире: Психолого-педагогические проблемы Новой школы. Национальный психологический журнал. 2010. № 2 (4). С. 6-11.

\section{REFERENCES}

1. Vyshkivska, V.B. \& Kushniruk, S.A. (2018). Do problemy formuvannia profesiinoi kompetentnosti vchytelia Novoi ukrainskoi shkoly [On the Problem of Forming the Professional Competence of the New Ukrainian School Teacher]. Scientific journal: due to scientific works "Pedagogical sciences, realities and perspectives.Vol. 64, pp. 44-48.[in Ukrainian].

2. Gendina, N.I. (2009). Informatsionnaya gramotnost v kontekste drugikh vidov gramotnosti: daidzhest zarubezhnogo opyta [Information literacy in the context of other types of literacy: a digest of foreign experience] School library. No. 9-10. pp. 28-39. [in Russian].

3. Hych, H.M. (2019). Uchni Novoi ukrainskoi shkoly yak nosii "novoi hramotnosti" i subiekty osvitnoho protsesu [Students of the New Ukrainian School as carriers of "new literacy" and subjects of the educational process]. Arts and education.No.1 (91). pp.12-14.[in Ukrainian].

4. Hych, H. M. (2016). "Klipove myslennia" ditei ta pidlitkiv yak fenomen suchasnoho navchalnoho protsessu ["[Clip-thinking of children and adolescents as a phenomenon of the modern educational process]. September. 2014. № 3-4. Pp. 14-19; Clip-thinking of young people: an enemy or a friend? Scientific works of the BSU Petro Mohyla: scientific method. view. issue. 257. Vol. 269. Pedagogy. Black Sea Petro Mohyla State University. 2014. No. 3-4.pp. 14-19; Mykolaiv, pp. 38-42.[in Ukrainian].

5. Kolesnikova, I. A. (2013). Novaya gramotnost i novaya negramotnost dvadtsat pervogo stoletiya[New literacy and new illiteracy of the twenty-first century]. Continuing Education: XXI Century.Vol.2. DOI: 10.15393/ j5.art.2013.2091 [in Russian].

6. Kontseptsiia Novoi ukrainskoi shkoly: Kontseptualni zasady reformuvannia serednoi shkoly [New Ukrainian School Concept: Conceptual Principles of Secondary School Reform]. Ministry of Science and Education of Ukraine.Kyiv, 2016.34 p.[in Ukrainian].

7. Liashenko, O.I. (2018). Problemy modernizatsii zmistu osvity $\mathrm{v}$ umovakh reformuvannia ukrainskoi shkoly
[Problems of Modernizing the Content of Education in the Conditions of Reforming the Ukrainian School]. Pedagogy and psychology.No.4, pp. 5-11.[in Ukrainian].

8. Medyntseva, I. P. Kompetentnisnyi pidkhid v osviti [Competent approach in education]. Pedahohichna maisternist: materialy II Mizhnar. nauch. konf. (m.Moskva, hruden 2012 roku) -_Teaching Skills: Proceedings of the II Intern. scientific Conf. (Moscow, December 2012).[in Ukrainian].

9. Savenkov, A.I. (2012). Metodika uchebnogo issledovaniya i proektirovaniya $\mathrm{v}$ praktike nachalnogo obucheniya [The methodology of educational research and design in the practice of primary education] Elementary School.No. 9. pp.54-61. [in Russian].

10. Selevko, G. K. (2006). Entsiklopediya obrazovatelnykh tekhnologiy: $\mathrm{v} 2$ t. Seriya "Entsiklopediya obrazovatelnykh tekhnologiy" [Encyclopedia of educational technologies: in 2 volumes. Series "Encyclopedia of educational technologies"]. Moscov, Vol. 1.535 p.[in Russian].

11. Frumin, I. D. Dobryakova, M. S. Barannikov, K. A. \& Remorenko, I. M. (2018). Universalnye kompetentnosti i novaya gramotnost: chemu uchit segodnya dlya uspekha zavtra. Predvaritelnye vyvody mezhdunarodnogo doklada o tendentsiyakh transformatsii shkolnogo obrazovaniya [Universal competencies and new literacy: what to teach today for tomorrow's success. Preliminary conclusions of the international report on school educational transformation trends]. Moscov, 28 p. Modern education analytic. No. 2 (19).[in Russian].

12. Fedorov, A.V. (2007). Razvitie mediakompetentnosti i kriticheskogo myshleniya studentov pedagogicheskogo vuza [The development of media competence and critical thinking of students of a Pedagogical University]. Moscov, 606 p. [in Russian].

13. Shykyrynska, O.V., Vyshkivska, V.B. \& Aleksandrovych, T.V. (2019). Mentalni karty u rozvytku matematychnoi kompetentnosti maibutnoho vchytelia pochatkovoi shkoly [Mental maps in the development of mathematical competence of a future elementary school teacher]. Aktualni problemy formuvannia tvorchoi osobystosti pedahoha v konteksti nastupnosti doshkilnoi ta pochatkovoi osvity : zbirnyk materialiv II Mizhnarodnoi naukovo-praktychnoi Internetkonferentsii (Vinnytsia, VDPU imeni Mykhaila Kotsiubynskoho, 17-18 kvitnia 2019 r.) - Topical Problems of Formation of Teacher's Creative Personality in the Context of Continuity of Preschool and Primary Education: Collection of Proceedings of the II International Scientific and Practical Internet Conference (Vinnytsya, Mykhailo Kotsyubynskiy State University, April 17-18, 2019) (Ed.).O.A.Holiuk; Vinnytsia, Vol. 8. pp. 183-185.[in Ukrainian].

14. Feldshteyn, D. I. (2010). Izmenyayushchiysya rebenok v izmenyayushchemsya mire: Psikhologopedagogicheskie problemy Novoy shkoly [A changing child in a changing world: Psychological and pedagogical problems of the New School]. National Psychological Journal. No. 2 (4). pp. 6-11.[in Russian].

Стаття надійшла до редакції 22.10.2019 